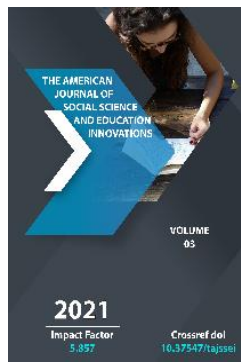

Journal Website: http://usajournalshub.c om/index,php/tajssei

Copyright: Original content from this work may be used under the terms of the creative commons attributes 4.0 licence.

\section{Foreign Language Teaching Methods}

\author{
Karimova Yulduz Malikovna \\ Teachers Of Namangan State University, Faculty Of World Languages, Namangan, Uzbekistan \\ Uzokov Bahodir Hamidullayevich \\ Teachers Of Namangan State University, Faculty Of World Languages, Namangan, Uzbekistan \\ Khojamova Naima Abdurashitovna \\ Teachers Of Namangan State University, Faculty Of World Languages, Namangan, Uzbekistan \\ Zoirova Tabarruk Abdugafforovna \\ English Teacher At School № 42 Namangan An English Teacher At School No. 42 In Namangan, \\ Namangan, Uzbekistan
}

\title{
ABSTRACT
}

This article describes the methods used in foreign language teaching and their importance.

\section{KEYWORDS}

Foreign language, pedagogical technology, form of teaching, interactive methods, didactic games, method, methodology, research, practical work.

\section{INTRODUCTION}

In the methodology of teaching a foreign language, the term "method" has three main meanings: first, a whole direction in the history of methodology (translation method, correct method, comparative method, mixed method); second, the teaching system that is part of the above direction (eg, François Guen method, Harold Palmer method, Michael West method, etc.); and third, the way teachers and students interact (methods of familiarization, practice, and application). In the history of foreign language teaching, the first and second 
are usually referred to as "historical" methods, and the third is referred to as "methods in foreign language teaching".

In methodology, historical methods consist of certain principles, and the set of principles forms a particular method. Process methods emerge through teaching methods, so teaching methods and teaching principles are discussed separately.

\section{MATERIALS AND METHODS}

Didactic, psychological and methodological principles can be used in teaching. Historically, methods have been grouped into four groups, with the words "translation", "correct (or without translation)", "comparative (or conscious-comparative)", "mixed" added to their names as determinants. it is said. Thus, all the methods of centuries-old history of foreign language teaching are grouped into these four categories. A brief analysis of each of them is required, as in today's methodology some of their features are used in a certain way.

Translation method. The name of this method is usually used interchangeably with the term "translation methods". It is not difficult to know the meaning of the name: foreign language material is translated into the native language. In Europe, translation was first used as a method of understanding Greek, and later Latin. During the second half of the 18th century and the 19th century, French was studied, and in the 2oth century, English, and finally German, was studied through translation. In the Muslim world, Arabic and Persian were studied as foreign languages. Dead (e.g., Latin) and living languages were taught by translation, a process that was considered a factor in the development of logical thinking. Arabic, on the other hand, was a means of teaching Islamic works, which most students learned by rote memorization. Arabic, Persian, Turkish, etc. are taught in religious schools. languages are studied.

The most common translation methods are known as "grammar-translation method" and "text-translation method". Proponents of the former used word and sentence translation to teach grammar, while proponents of the latter aimed to use translation in reading the text and understanding its content. The use of both translation methods is for educational purposes only. A foreign language is learned receptively. Based on the linguistic and psychological knowledge of the time, foreign language teaching methods were developed.

Some teachers still misuse translation methods. Mas. interpreting a text is a nonmethodical method. It is not forbidden to translate certain sentences or parts of the text for a specific purpose. The dictionary can be used to provide short texts to explain the meaning of new words. The purpose of translating the text here is to teach the use of a dictionary. The main reason for the origin of the name of the method is that when teaching in the right method, try to establish a direct association (thought connection) between the word of a foreign language and the subject, bypassing the native language. rilgan. The same method was used to teach foreign language grammar: they wanted to make a direct connection between grammatical meaning and form.

The right method. The main reason for the origin of the name of the method is that in the right method of teaching there is an attempt to establish a direct association between the 
word of the foreign language and the subject, bypassing the native language. The same method was used to teach foreign language grammar: they wanted to make a direct connection between grammatical meaning and form. The reason for the birth of the right method can be traced to the practical study of foreign languages. By the end of the last century, this method was invented as a result of the reform of foreign language teaching in Western Europe and the United States. The method later spread to Asia, Africa and other continents.

Attempts to teach a foreign language without the participation of the mother tongue began to be expressed in terms such as the correct method, the inductive method, the natural method.

The main purpose of these methods is to teach a foreign language in a practical way. The conditions for learning the mother tongue remained the same in this method.

Two of the modern forms of the correct method are audiolingual and audiovisual. According to the founders of the audiolinguistic method (famous American Methodists Charles Carpenter Frieze and Robert Lado), a foreign language is studied for practical and educational purposes. Emphasis is placed on the selection and teaching of foreign language sentences (speech patterns) from language materials. The procedure for studying the types of speech activities is as follows: listening comprehension speaking-reading - writing. Spoken language is taught as a means of communication in a foreign language, and written speech is taught on the basis of oral material.
Teachers know several positive features of the audiolingual method from school experience. For example, the use of speech patterns at the level of language teaching units, the advancement of oral speech, and the teaching of reading and writing in oral material have been adopted with appropriate changes in grades V-VII.

Some of the laws of the audiolingual method do not apply to our conditions, as noted in the textbooks. Distinguishing between active and passive language material, they are indifferent to their acquisition, which is also a misguided methodological guide.

In addition to the commonality of the two methods (including the correct method), there are differences. Mas. the audiovisual method teaches speaking, writing, and finally reading. Reading is taught after writing. Some aspects of this method are used creatively in our schools. In the first year of high school, foreign language teaching is taught before writing, then reading before writing, and reading in the upper grades before all types of speaking activities.

Reproductive (H. Palmer) and receptive ( $M$. West) foreign language teaching methods have also left a significant mark on the history of methodology. They are covered in Chapter VII.

Mixed method. It is obvious that this method combines the scientific and practical aspects of two methodological directions. Mixed methods emerged in the late 19th and early 2oth centuries as a mixture of taijima and correct methods. Its representatives can be found in the works of the Danish psychologist K. Flagstad, the German linguist E. Otto, the 
German Methodist F. Aronstein, and the German linguist $\mathrm{G}$. Paul.

Another form of the mixed method emerged as a mixture of the principles of the correct method and the comparative method. Representatives of this modern mixed method are Methodists P. Hegboldt of the United States, F. Klosse of Belgium, A. Bolen of Germany, and the Russian foreign language psychologist V. V. Belyayev is known and famous for his research.

Both aspects of the mixed method do not have their own specific principles, but are more prone to a particular method, as well as a combination of the principles of the two methods.

Comparative method. Its full name is the "comparative method". The founder of this method is acad. Prof. L. V. Shcherba, a corresponding member of the Academy of Pedagogical Sciences, who adapted the method to the modern process of teaching foreign languages, continued the work of the founder of the method. I. V. Rakhmanov. When teaching a foreign language by the comparative method, they began to work on the principle of didactic consciousness. The special principles of this method, such as comparison, work on the basis of the native language, simultaneous teaching of speech activities, were formed in the forties and fifties of the last century and are widely used in practice. The practical, educational and pedagogical goals of foreign language teaching are scientifically based. This was the first version of the method.

From the 1960s to the present, the comparative method has been modernized, and its principles have been studied in accordance with new requirements. For example, comparisons are not a matter of your student's work in the classroom, but a matter for the methodologist and the teacher to create a system of exercises.

In the first form of the comparative method, exercises were performed on the basis of rules, while in the modern form, the rules of practice are generalized in the process of exercise. The student is not specifically involved in comparisons, memorization and narration of rules, or the acquisition of theoretical knowledge.

\section{RESULTS}

The first concept that defines the term "method" is the historical direction of foreign language teaching methods. In the second sense (teaching system - Palmer, West, Guen methods). The third aspect of the term "method" in the sense of teacher-student activity method is discussed below.

There are three methods used in foreign language teaching: familiarization, practice and application. These three terms have been used under different names in methodological research. These methods, which are widely accepted and can be directly observed in teaching, are named from the point of view of the reader. The student's task in learning a foreign language is to get acquainted with the study material (ie language material), to practice in order to develop skills and competencies, and to express their opinion, that is, to communicate in language. use.

As a foreign language teaching system, it involves two parties - the teacher and the learner. The teacher is responsible for 
organizing the student's learning activities. The teacher organizes the three tasks that the student does: acquaintance, practice, and application. In addition to the lessons, the teacher's organizational task is to develop skills and competencies for independent work.

The next task of a teacher is to teach. An educational task is the teaching of a language to a student through explanation or demonstration, narration, interpretation, and correction. The teacher teaches the foreign language material or shows the way to learn from the textbook / tape recorder, and gives a concise explanation of a complex language phenomenon if the student has difficulty.

Supervision is the third of the teacher's responsibilities. Determines students' level of understanding as they become acquainted with new material. He observes that he is doing the wrong thing. Controls the performance of speech activities during the placement of language material. Mas. to understand the content of a text read aloud, students must have mastered the lexical units in it. If the student has forgotten the material, the teacher arranges to repeat the lexical material.

As mentioned above, students can complete tasks through familiarization, practice, and application methods. Each method has its own characteristics.

Acquaintance is the first step in learning the material. As the student begins to study the unit of language, he or she learns its form (clearly hearing the sound side in oral speech or reading a graphic representation from a written text), its meaning (object, event, action, thought link and use (in combination with other units, in what case). Form, meaning, and usage are three aspects that are studied in each lexical or grammatical unit. Getting to know them is the beginning of learning.

\section{CONCLUSION}

One of the basic conditions for memorizing this unit is to perceive it through the senses of hearing and sight. At this point, the language unit goes through a training phase. Through practice, the language phenomena studied are strengthened and a dynamic stereotype is formed about them. This dynamic stereotype is triggered in the operational status of the speech process.

The third step is to use language material for practical communication. During the application period, information exchange (ie skills development) exercises are performed.

The tasks that students learn, practice, and apply are called teaching methods in the language of methodology. They are also called "teaching methods".

\section{REFERENCES}

1. Nurmatova M.R. Body Part Idioms in English and Uzbek: A Contrastive Analysis and Teaching Implications. Молодой ученый, 2016, с. 915-917

2. Richard A, Spears, Ph.D. NTC's American idioms dictionary. USA, 2000, p.94

3. Amy Gillet. Speak English like an American. USA, 2004, p.60

4. Yo'ldosheva Z.K., Jumanazarova Sh.Z. The comparison of the lingua-cultural idioms that are commonly used in English, Uzbek and Russian languages. Молодой ученый, 2016, с. 730-732

5. Gerhard Neuner und Hans Hunfeld Foreign Language Teaching Methods. - 


Namangan 2005 (translated from
German).
6. Yuldashev J. Problems of new
pedagogical technologies.-1999.
7. Abdinazarov Sh. Actual issues of
education.- Karshi, 1991.
Kleppin, K. Fehler und
Fehlerkorrektur.-Berlin Munchen.
Langenscheidt 2002.
Zaripova F.A. Handbook of foreign
language teaching methods.-
Tashkent, 2002.
Hoshimov O'.H, Yokubov I.YA.
Methods of teaching English.-
Tashkent, 2003.
Rogova G.B., Rabinovich F.M.,
Sakharov T.E. Teaching methods
Hoshimov O'.H., Yokubov I..YA.
Methods of teaching English.-
Tashkent, 2003.

13. Kadyrova F. R. Pedagogical education.Tashkent, 2002.

14. Yuldashev J. Problems of new pedagogical technologies.-1999. 